\title{
Orman Yolu Güzergahlarının Belirlenmesinde Farklı Tekniklerle Üretilmiş Sayısal Arazi Modellerinin Kullanılması Üzerine Bir Araştırma
}

\author{
Sercan GÜLCI ${ }^{1 *}$, Mustafa AKGÜL ${ }^{2}$, Neşe GÜLCI ${ }^{1}$, Murat DEMİR ${ }^{2}$ \\ ${ }^{1}$ Kahramanmaraş Sütçü İmam Üniversitesi, Orman Fakültesi, 46040, Kahramanmaraş \\ ${ }^{2}$ İstanbul-Cerrahpaşa Üniversitesi, Orman Fakültesi, 34473, İstanbul
}

\begin{abstract}
Öz
Doğal yaşam alanlarındaki mühendislik çalışmaları, olabildiğince doğru veriler gerektirir. Ormanların ekolojik, ekonomik ve estetik koşulları üzerindeki doğrudan veya dolaylı etkilerini optimize etmek veya azaltmak için, çok boyutlu analizler ve mevcut verilerin kullanılmasıyla desteklenen güncel teknolojik önlemlere ihtiyaç vardır. Ormanlarda yol ağlarının yapımı sırasında ve sonrasında habitatlarda geri dönüşü olmayan sonuçlar gözlemlenebilir. Bu etkiler bozulma, kayıp ve parçalanma olmak üzere üç ana başlıkta toplanabilir. Orman üzerinde karşılaşılabilecek olumsuzlukların azaltılması için kuşkusuz teknolojiden yararlanmak gerekmektedir. Bu çalışmada, Kahramanmaraş Sütçü İmam Üniversitesi (K.S.Ü) Araştırma ve Geliştirme Ormanı sınırları içerisinde yol ağı planlamasında kullanılabilecek üç teknikle üretilmiş SAM (sayısal arazi modeli)'nin kazıdolgu ve yol güzergâhı tespitinde durumları karşılaştııılmıştır. Değerlendirilen veriler, 1/25000 ölçekli topoğrafik harita, SRTM (Shuttle Radar Topography Mission) ve RTK-GPS (Real Time Kinematic-Global Position System) tabanlı verilerdir. Üç teknikle üretilen SAM'lar kullanılarak, ArcGIS ortamında en düşük maliyetli güzergâh analizi gerçekleştirilmiştir. Sonuçlara göre $1 / 25000$ ölçekli topoğrafik harita kaynaklı üretilen veri setine göre elde edilen toplam kazı $50,04 \mathrm{~m}^{3}$ olarak hesaplanmış ve dolgu miktarı 23,46 $\mathrm{m}^{3}$ olarak hesaplanmıştır. SRTM tabanlı yöntemde elde edilen toplam kazı 38,58 $\mathrm{m}^{3}$ ve dolgu miktarı $34,37 \mathrm{~m}^{3}$ 'tür. RTKGPS yöntemine göre toplam kazı ve dolgu miktarı $89,95 \mathrm{~m}^{3}$ ve $27,23 \mathrm{~m}^{3}$ ’tür. Toplam 991,57 m uzunluğa sahip örnek yolda, maksimum kazı miktarı RTK-GPS $>$ SRTM $>1 / 25000$ ölçekli topoğrafik harita tabanlı olarak belirlenirken, toplam dolgu hacmi miktarları sırasıyla SRTM>1/25000 ölçekli topoğrafik harita> RTK-GPS olarak belirlenmiştir.
\end{abstract}

Anahtar Kelimeler: Orman yolları, Ölçme, DEM, Topoğrafik haritası, SRTM, RTK-GPS.

\section{A Study on Using Digital Terrain Models Produced by Different Techniques in Determining Forest Road Routes}

\begin{abstract}
Engineering research on natural habitats requires as accurate data as possible. In order to optimize or reduce the direct or indirect impact on the ecological, economic and aesthetic conditions of the forest, the latest technological measures, supported by multi-dimensional analysis and the use of available data, are required. During and after the construction of road networks in forest, irreversible results can be observed in habitats. These effects can be summarized into the three main concepts of degradation, loss and fragmentation. There is no doubt that technology must be used to reduce possible negative effects on forest. In the study, three different DTMs (digital terrain models), which can be used in road network planning within the boundaries of Kahramanmaras Sutcu Imam University (K.S.U) Research and Development Forest, was compared according to the effectiveness of these DTMs in excavation-embankment and determining the road route. The evaluated data sets were 1/25000 scaled topographic map-based, SRTM (Shuttle Radar Topography Mission)-based and RTK-GPS (Real-Time Kinematic - Global Position System)-based data. The least cost route analysis was performed in the GIS ArcGIS 10.1 software environment, using DTMs produced with the three techniques. The results indicated that the total amount of excavation obtained in the method based on the contour map was calculated as $50.04 \mathrm{~m}^{3}$ and the amount of embankment as $23.46 \mathrm{~m}^{3}$. The total excavation obtained in the SRTM-based method was $38.58 \mathrm{~m}^{3}$ and the amount of embankment was $34.37 \mathrm{~m}^{3}$. According to the RTK-GPS method, the total amount of excavation and embankment was $89.95 \mathrm{~m}^{3}$ and $27.23 \mathrm{~m}^{3}$, respectively. On the sample road with a total length of $991.57 \mathrm{~m}$, the maximum excavation amount was determined as RTK-GPS> SRTM $>1 / 25000$ scaled topographic map based method DTM, while the total embankment amounts were determined as SRTM>1/25000 scaled topographic map> RTK-GPS based method.
\end{abstract}

Keywords: Forest roads, Surveying, DEM, Topographic map, SRTM, RTK-GPS.

\begin{tabular}{lll}
\hline *Sorumlu Yazar (Corresponding Author): & Geliş (Received) : 01.04 .2021 \\
Sercan GÜLCİ (Doç. Dr.); KSÜ Orman Fakültesi, Orman Mühendisliği Bölümü, & Kabul (Accepted) : 30.06 .2021 \\
46040, Kahramanmaras-Türkiye. Tel: +90 (344) 300 1749, Fax: +90 (344) 300 1712, & Basım (Published) : 15.08.2021 \\
E-mail: sercangulcu@gmail.com, ORCID: 0000-0003-3349-517X & (P)
\end{tabular}




\section{Giriş}

Ormanların işletmeye açılmasında ön koşul olan orman yolları, yıl boyunca ulaşım ve üretim araçların ormancılık hizmetlerinin yerine getirilmesi amacıyla kullanılmaktadır (Erdaş, 1997). Orman yollarının asli görevi gerek orman ürünlerinin gerekse işçi taşınmasının duraksamadan güvenli ve emniyetli bir şekilde sağlamaktır. Kısaca orman yollarının güvenli bir transport amacıyla planlanması esastır (Akgul vd., 2016a). Bununla birlikte doğala en yakın yol güzergâhlarının planlanması mutlak suretle göz önünde bulundurulmaktadır. Zira, yol inşaatının başladığ 1 ve bittiği noktalar arasında yaşam alanları üzerinde dolaylı veya doğrudan birçok etki ortaya çıkmaktadır (Lugo ve Gucinski, 2000; Tunay, 2006; Gümüş vd., 2008; Eker ve Çoban, 2010; Boston, 2016; Gülci vd., 2017a). Dolayısıyla, orman yol ağı planlanma aşamalarında uygun ölçüm tekniği ve araçları kullanılarak en az hataya sahip veriler kullanılmalıdır. Böylece ekolojik, ekonomik, ergonomik ve estetik kayıpların değerlendirilmesinde daha gerçekçi öngörüler ortaya çıkmaktadır. Bu nedenle orman yollarının planlanmasında geleneksel yöntemlerden daha ziyade bilgisayar ve yazılım destekli çalışmalar ön plana çıkmaktadır. Son yıllarda, sürdürülebilir ormancılık çalışmaları kapsamında bilgisayar destekli orman yol planlamaları teşvik edilmekte ve yaygınlaşmaktadır (Akay, 2004; Lepoglavec vd., 2012; Hayati vd., 2013).

Ölçme ve değerlendirmede para ve zaman bakımından yarar sağlayan araçların orman yolları planlanmasında ve tasarlanmasında önem arz ettiği genel kabul gören bir yaklaşımdır. Zira orman yolları inşaatı öncesinde ve sonrasında ormanlık alanlarda gerçekleştirilecek her türlü müdahale sonucunda doğrudan ve dolaylı etkilere maruz kalmaktadır. Bu etkiler çoğu zaman ormanlık alanlarda kalıcı tahribatlara neden olabilmektedir. Yine bu etkilerin değerlendirilmesinde uzaktan algılama ve CBS verilerinin değerlendirilmesi orman yollarının planlama çalışmaları açısından önemlidir. Ormancılık çalışmalarında yüksek hassasiyette SAM verilerinin elde edilmesinde yer, hava ve uzay platformlardan faydalanılmaktadır.

Nitel ve nicel olarak değerlendirilmesi gereken birçok karar değişkeninin dahil edildiği yol projelendirme modellerinin oluşturulması ve senaryoların değerlendirilmesiyle sürdürülebilir fonksiyonel orman yolu çalışmaları gerçekleştirilmektedir (Demir, 2007; Abdi vd., 2009; Hayati vd., 2013; Acar vd., 2017; Tampekis vd., 2015). Yolların projelendirilmesinde maliyeti en aza indirebilecek veri setleri arasında topoğrafik ve jeolojik faktörler en dikkati çeken maliyet değişkenlerindendir (Akay vd., 2018). Orman yollarının planlanmasında topoğrafik etmenler başta olmak üzere ekocoğrafik verilerinde bir araya getirilerek gereken nitel ve nicel verilerin bilgisayar destekli uygulamalar yardımıyla, açık ve anlaşılır modeller haline getirilebilmektedir (Chung ve Sessions, 2001; Akay ve Sessions, 2005; Najafi ve Richards, 2013; Gülci ve Akay, 2015). Nitekim yol planlama çalışmaları öncesi ve sonrası çevresel etki değerlendirilmede uzaktan algılama ve CBS kullanımı gereklidir (Arıcak ve Acar, 2008; Akay vd., 2014; Aricak, 2015; Grigolato vd., 2017).

Sayısal arazi modeli (SAM); orman inşaatı, tomruk üretim çalışmaları, kadastrosu ve diğer birçok planlamayı içeren mühendislik çalışmalarında materyal olarak kullanılmaktadır (Heinimann, 2017). SAM verilerinin elde edilmesinde birçok farklı yöntem bulunmaktadır. Bunlar yer ölçüm teknikleri (GPS, Total station gibi), mevcut topoğrafik haritalar, fotogrametri (yer, hava ve uzay platformları) ile elde edilen sayısal görüntülerden olmak üzere üç farklı şekilde SAM elde edilmektedir (Nelson vd., 2009). Orman yollarının planlanmasında topoğrafik haritalar, takeometrik ölçümler, küresel konumlama sistemi (KKS-GPS) ve fotogrametrik tekniklerden faydalanılmaktadır. Ayrıca, son yıllarda radar ve lazer algılayıcı sistemlerin kullanımı artmıştır. Teknoloji ve CBS'deki gelişmeler SAM'ın mühendislik çalışmaları içeren alanlarda kullanımının önemini arttırmakta ve dolayısıyla elde edilen verilerin kalitesi üzerine değerlendirmeleri gerekli kılmaktadır (Gümüş vd., 2003; Aslan, 2005; Abdi vd., 2012; Wilson, 2012; Akgul vd., 2018; Yurtseven, 2019).

Orman yolları inşaatı öncesinde-sonrasında kazı ve dolgu dengesinin sağlanması, materyal taşıma hacmi gibi inşaat işlerinin optimize edilmesinde, yer kontrol noktalarının tespitinde, kardinal noktaların tespitinde, fotogrametrik çalışmaların gerçekleştirilmesinde ve ormancılık çalışmalarının birçok alanında kullanılmaktadır (Akgül vd., 2016b; Akgul vd., 2018). Orman yolu planlama çalışmalarında diğer faktörlere oranla önem düzeyi oldukça yüksek olan topoğrafik veri (Abdi vd., 2009), üretiminde geniş kullanım alanına sahip eş zamanlı küresel konumlandırma sistemi (RTK-GPS) mühendislik çalışmalarında zaman ve maliyet açısından verimli ve yüksek hassasiyete sahip SAM verileri üretiminde kullanılmaktadır (Zhang vd., 2014; Yurtseven, 2019).

Orman yollarının planlanmasında yüksek hassasiyetle oluşturulan SAM’nin olumlu etkisi şüphesiz kabul edilen genel bir gerçektir. İnşaat çalışmalarından önce elde edilen ölçümlerin hassasiyetine bağlı olarak inşaat-çevre ilişkileri ortaya konulmaktadır. Günümüzde farklı ölçme teknikleri kullanılarak oldukça hassas 
nitel verilerin temin edilmesi kolaylaşmıştır. Başta uzaktan algılama yöntemleri olmak üzere, CAD ve CBS tabanlı karar destek sistemlerinin orman yolu planlama-projelendirme, inşaat ve inşaat sonrası değerlendirme aşamalarında kullanım alanı bulunmaktadır (Öztürk, 2009; Lepoglavec vd., 2012; Türk, 2019). LiDAR (Light detection and ranging) ve IFSAR (Interferometric synthetic aperture radar) gibi temini oldukça pahalı radar ve lazer teknolojileri SAM üretiminde kullanıldığı gibi maliyeti daha uygun eş zamanlı kinematik küresel konumlandırma sistemi (RTK-GPS), Total Station kullanımı ve fotogrametrik yöntemler ile topoğrafik veriler elde edilmektedir (Akay vd., 2009; Gülci vd., 2015). Bu veriler proje yapım aşamalarında harcanan zamanı en aza indirmektedir (Lepoglavec vd., 2012). Bu nedenle, farklı araç ve yöntemler yardımıyla üretilen SAM verilerinin ormanlık alanlarda gösterdiği performans konusunda araştırmalar hızla yaygınlaşmaktadır (Şentük vd., 2018; Akturk ve Altunel, 2019; Yurtseven, 2019). Farklı teknolojik özelliklere sahip araç ve gereçler kullanılarak elde edilen veriler artık kolayca denetlenebilmektedir.

Bu nedenle, bu çalışma kapsamında üç farklı teknikle elde edilen SAM verilerinin ormanlık bir alanda planlanacak örnek bir yol güzergâhında performansı araştırılmıştır. Gen koruma statüsüne sahip alanda bulunan eski bir sürütme yolunun başlangıç ve bitiş noktaları ile güzergâhı dikkate alınarak sayısal ortamda kazı-dolgu farklılıkları için karşılaştırmalar gerçekleştirilmiştir. Ayrıca, üç farklı teknikle üretilen SAM verileri için en uygun maliyetli güzergâh analizi gerçekleştirilmiştir. Böylece SAM'nin alternatif güzergâhların tespitindeki durumu değerlendirilmiştir. Sonuç olarak CAD ve CBS ortamında SAM verilerinin yol planlamada bazı etkileri araştırılmıştır.

\section{Materyal ve Metot}

\section{1. Çalışma alanı}

Çalışma alanı olarak Kahramanmaraş Orman Bölge Müdürlüğü, Kahramanmaraş Orman İşletme Müdürlüğü, Başkonuş Orman İşletme Şefliği, K.S.Ü Araştırma ve Uygulama Ormanı içerisinde bulunan üretim ve koruma fonksiyonuna sahip alanlar bulunmaktadır. K.S.Ü Araştırma ve Uygulama ormanı 32, 33, 48, 49 ve 84 nolu bölmelerden (toplam 365,0 ha alan) oluşmaktadır. (Şekil 1). Başkonuş Orman İşletme Şefliği toplam alanı 50720,5 ha olup bunun 30165,0 ha’1 ormanlık alandır (OGM, 2012). Araştırma alanı, 37³3'30" 37³6'30" Kuzey enlemleri ile 36³4'00" - 36³6'30" Doğu boylamları arasında yer almaktadır.

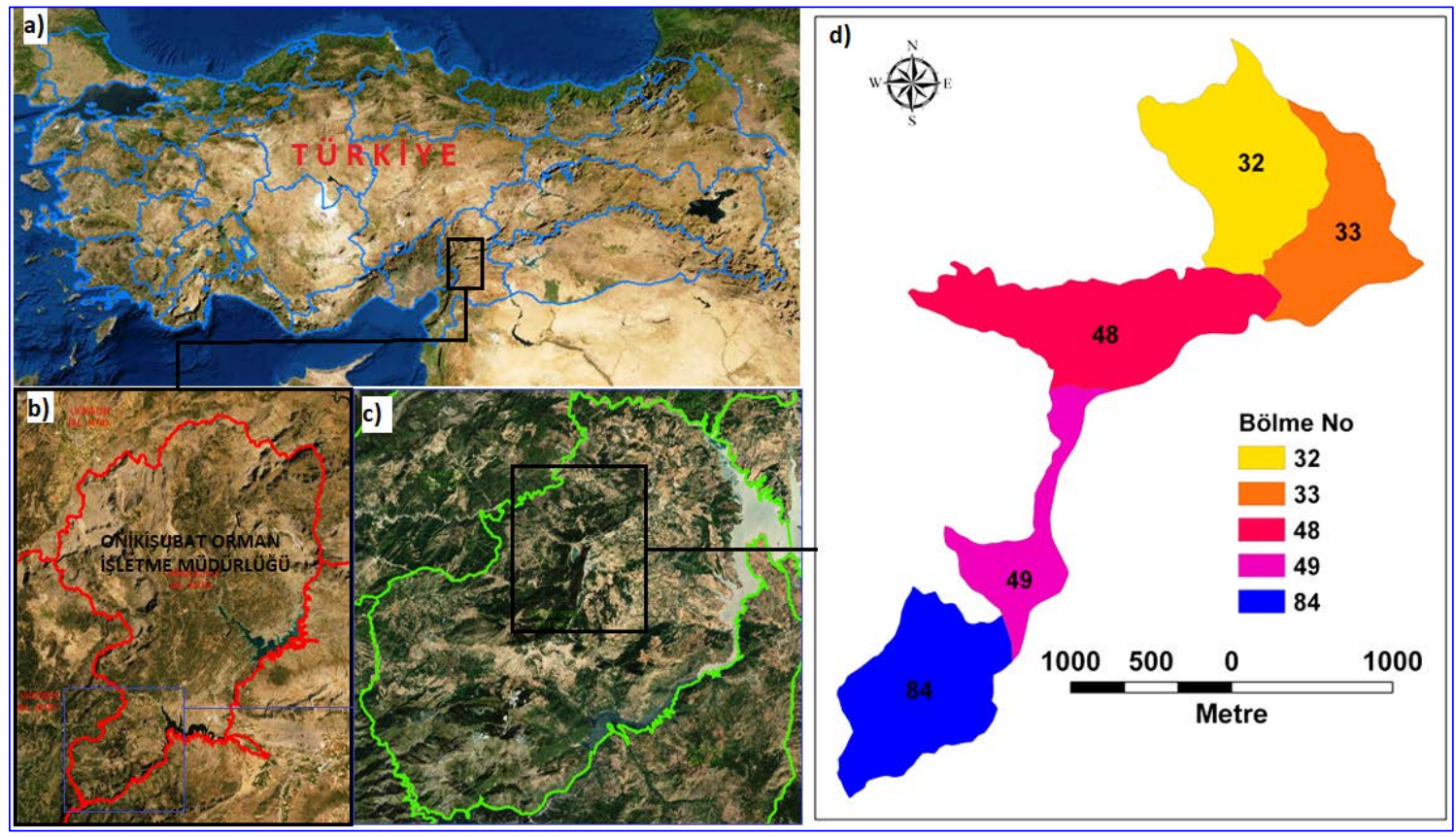

Şekil 1. Çalışma alanının ülke içindeki bağlı bulunduğu a) bölge, b) işletme müdürlüğü, c) şeflik sınırları içerisindeki coğrafi konumu ve d) K.S.Ü Araştırma ve Uygulama Ormanı sınırları.

Bu bölgenin çalışma alanı olarak seçilmesinin nedeni, arazi yapısının kısmen dağlık ve yüksek eğimli olması nedeniyle klasik sürütme yöntemleri ile kalın çaplı orman ürünlerinin bu bölgeden taşınmasının zor ve masraflı olmasıdır. Orman ürünlerinin üretiminden kaynaklanan tomruk hasarlarının azaltılması (nitel ve nicel 
kayıpların azaltılması), ayrıca fonksiyonel bir yol projesi ihtiyacı olan araştırma ve uygulama ormanında ergonomik, ekonomik, estetik ve ekolojik bakımdan uygun yol tasarımı ihtiyacı, çalışma alanının belirlenmesinde etkili olmuştur. Ayrıca, ana çalışma alanı olan 84 no'lu bölme gen koruma ormanı statüsünde olup üretim fonksiyonu bulunmamaktadır. Çalışma alanı içerisinde örnek bir yol güzergâhı farklı SAM kaynaklarına göre değerlendirilmiştir. Meşcere kuruluşları bakımından türlerin genel dağılışı Karaçam (Pinus nigra), Göknar (Abies cilicica) ve Sedir (Cedrus libani) ağırlıklı olarak 2 kapalı saf ve karışık yapıdadır (OGM, 2012). Arazi yapısı ve aktüel arazi kullanım durumların ortaya konulması aşamasında 1/25000 ölçekli topoğrafik haritalar ve orman amenajman haritaları kullanılmıştır.

\subsection{Metot}

Çalışmanın ilk aşamasında farklı veri kaynaklarından Sayısal Arazi Modeli (SAM) üretilmiş, ikinci aşamasında ise söz konusu SAM kullanılarak planlanan orman yolunda kazı-dolgu hesaplamalarındaki farklılıklar incelenmiştir. Üç farklı SAM verisi kullanılmıştır. Söz konusu veriler; SRTM verisi, 1/25000 ölçekli topoğrafik harita ve RTK-GPS tabanlı türetilen SAM'dir.

SAM üretiminde M37D4 numaralı 1/25000 ölçekli topoğrafik harita sayısallaştırılarak elde edilen eşyükselti eğrili haritadan yararlanılmıştır. ArcGIS 10.1 yazılımı ortamında, bilimsel çalışmalarda yaygın olarak kullanılan $10 \mathrm{~m}$ çözünürlüklü SAM elde edilmiştir. Ayrıca, çalışma alanında SRTM (Shuttle Radar Topography Mission) verisinin yaygın kullanımı ve hassasiyeti göz önünde bulundurularak kullanılmıştır (Gülci vd. 2017b). SRTM 1 Versiyon 3 verisi, 30 m çözünürlüğündedir ve https://earthexplorer.usgs.gov/ adresinden temin edilmiştir.

Yüksek çözünürlükte ve hassasiyette SAM oluşturulması amacıyla "North Smartk" marka gezici eş zamanlı kinematik (RTK-Real Time Kinematic) küresel konumlandırma sistemi kullanılmıştır (Şekil 2). Dâhili anten ve radyo modemi bulunan bu alıcılar ile baz istasyonları aracılığıyla iletişım kurulabilmektedir. Gezici olarak kullanılan GPS-GNNS ise radyo modemlerle iletişim kurabilmekte ve düzeltme değerlerini almaktadır. RTKGPS ile kontrol ve kayıt işlemleri anlık olarak gerçekleştirilmiştir. Bu çalışmada, gezici olarak çalışan GPS alıcısına entegre olan GSM modemler ile internet ağına bağlanarak TUSAGA (Türkiye Ulusal Sabit GPS Ağı) üzerinden yüksek doğrulukta veriler elde edilmiştir. GPS verilerinin referans zamanı olarak hassas en az $(3 \mathrm{~cm})$ veri sağlayan 3 Epok veri alımı tercih edilmiştir (Gülci vd., 2015a).

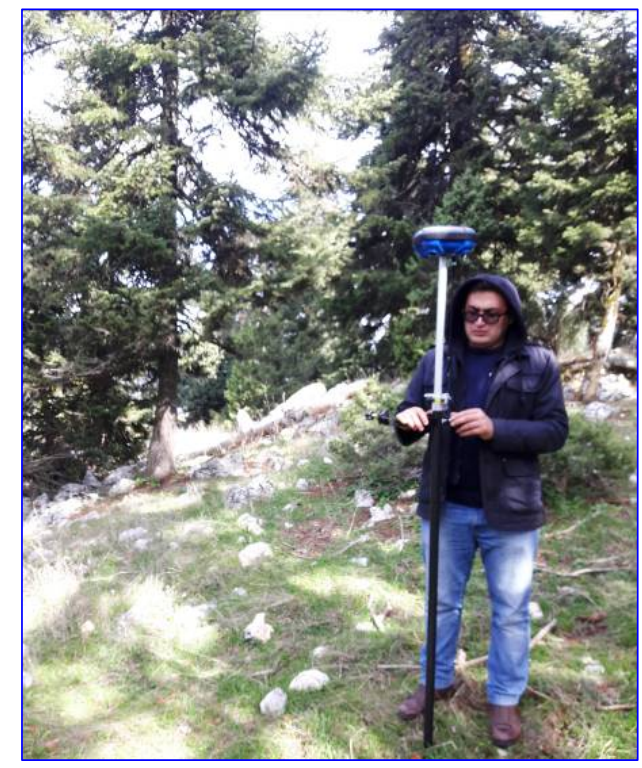

Şekil 2. Arazi aşamasında RTK-GPS kullanımı.

Konumsal alımı gerçekleştirilen yükseklikler elipsoidal yükseklik olup, haritalarda kullanılmakta olan deniz yüzeyine indirgenmiş ortometrik yükseklik sistemine ondülasyon verisi kullanılmıştır. Ondülasyon dönüşümünde, çalışma hassasiyetimizi karşılamasından dolayı çalışma alanımızı kapsayan dört farkın ortalaması alınarak dönüştürme işlemi gerçekleştirilmiştir. GPS alıcısından elde edilen X, Y değerleri ve ortometrik yüksekliğe dönüştürülen $\mathrm{Z}$ değerleri kullanılmıştır. ArcGIS 10.1 yazılımına aktarılan konumsal bilgilerden TIN (Triangular Irregular Network) modeli ve SAM oluşturulmuştur. Üretilen veriler için 6 
derecelik Universal Traverse Merkator (UTM) European Datum 1950 ve WGS 1984 koordinat sistemleri tercih edilmiştir. SRTM SAM verisi için coğrafi düzeltmeler GNNS ile elde edilen veriler kullanılarak gerçekleştirilmiştir. Yine eşyükselti eğrilerinden elde edilen SAM coğrafi düzeltmelerinde GNNS ile toplanan veriler kullanılmıştır. Sonuç olarak veri setleri aynı koordinat düzleminde değerlendirilmiş ve toplam hata değerleri yaklaşık 0,6 m olarak tespit edilmiştir.

Çalışma kapsamında ormanlık alan içeresinde planlanan örnek yol projelendirme aşamasında OGM tarafindan belirtilen yatay geometrik (292 sayılı tebliğ) hususlar ve standartlar göz önünde bulundurulmuştur (OGM, 2008). Ancak, söz konusu alanda farklı SAM modellerine bağlı olarak ortaya çıkacak kazı-dolgu farklarını tespit etmek amacıyla standardın dışında yüksek boyuna eğimler kullanılmıştır. Bilgisayar tabanlı yol projelendirilmesi AutoCAD Civil 3D yazılımı kullanılarak hesaplamalar gerçekleştirilmiştir. Planlama ve projelendirilme aşamasında Karayolları Genel Müdürlüğü yol planlama stili orman yolu projelendirme stillerine dönüştürülerek Türkçe stiller oluşturulmuştur. Farklı veri kaynaklarından türetilen SAM modellerinin orman yolu planlamasında sonuçların değerlendirilmesi için öncelikle çalışma kapsamında planlanan yol güzergâhı AutoCAD Civil 3D yazılımında sırasıyla yatay profil, düşey profil tanımlaması, yol koridoru oluşturulması, tip kesit tanımlaması, en kesitlerin çizdirilmesi ve kübaj hesaplaması işleri takip edilmiştir. Planlama sonucunda elde edilen 3 farklı kaynak SAM'den elde edilen kazı-dolgu değerleri hesaplanarak ortaya konmuştur.

Ayrıca, üretilen SAM'ler arasındaki yol projelendirilmesi aşamasında alternatif güzergâhları ortaya koyabilmek için en uygun maliyetli güzergâh analizleri gerçekleştirilmiştir. SAM'ler kullanılarak elde edilen eğim haritaları altlık veri olarak kullanılmıştır. Bu analizde kazı-dolgu hacim hesabı yapılan güzergâhtan farklı olarak alternatif güzergâhlar tahmin edilmiştir. En uygun kümülatif maliyetli güzergâhın belirlenmesinde Queen's modeli (3x3 piksel) kullanılmıştır (Adriaensen vd., 2003; Yu vd., 2003; Gülci ve Akay, 2015). Pikseller arasındaki komşuluk ilişkilerini değerlendiren bu yöntemde, kaynak noktadan hedef noktaya ulaşmakta en uygun ve en kısa mesafede ulaşımı sağlayabilecek düşük eğimli güzergâh tahmini ortaya konulmaktadır. Yolların inşaat maliyeti için hesaplamalar gerçekleştirilmemiştir.

\section{Bulgular}

\subsection{Sayısal arazi modelleri}

Farklı veri setlerinden elde edilen SAM'ler ArcGIS yazılımı ile işlenerek modellenmiş ve görselleştirilmiştir. Bu modeller Şekil 3'te verilmiştir. RTK-GPS yardımıyla üretilen SAM ve araştırma alanı sınırları Şekil 4'te verilmiştir.

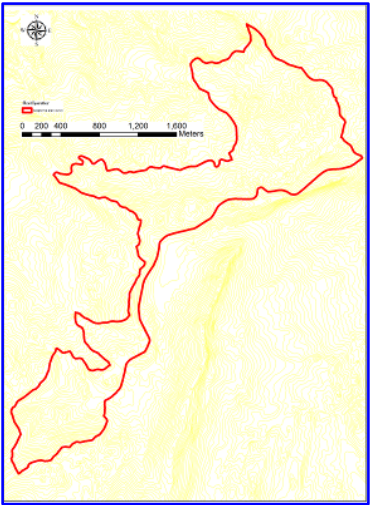

(a)

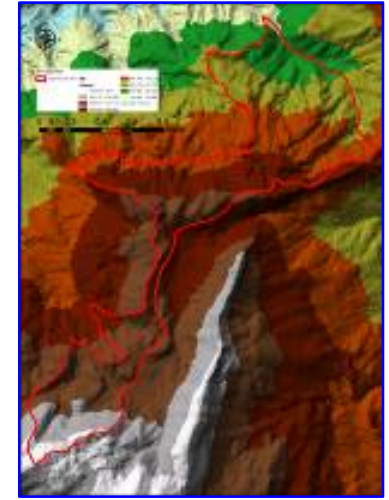

(b)

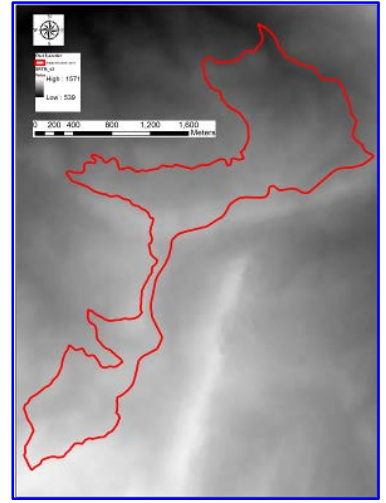

(c)

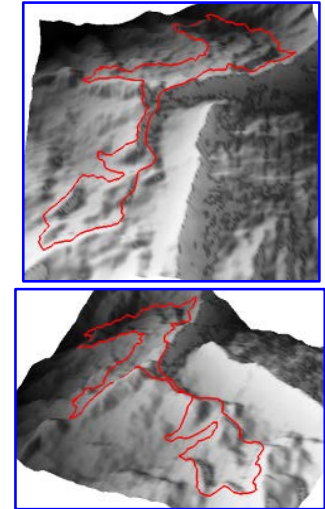

(d)

Şekil 3. Çalışma alanı konumuna ait gösterim ve veri tabanına ait örnekler. a) 1/25000 ölçekli topoğrafik harita kaynaklı eşyükselti eğrileri, b) topoğrafik harita kaynaklı TIN verisi, c) uydu görüntüsünden elde edilen SAM (SRTM V3) ve d) SAM 3 boyutlu (3B) modelin farklı açılardan görünümü. 


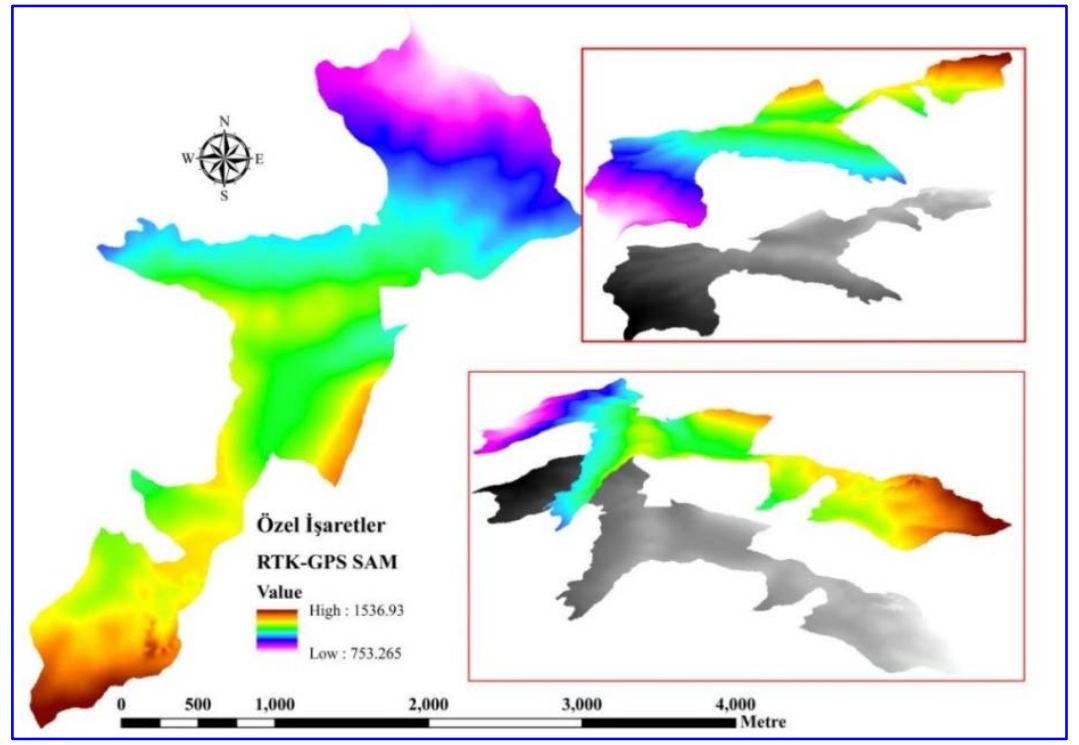

Şekil 4. RTK-GPS ile üretilen SAM ve farklı açılardan görünümü.

\subsection{Farklı SAM verilerine göre kazı-dolgu sonuçlarının değerlendirilmesi}

Çalışmaya konu olarak planlaması yapılan yaklaşık 992 m uzunluğunda yol güzergâhına ait planlama çalışması gerçekleştirilmiştir. Bu yolun uzunluğu çalışma alanında daha önce var olan ancak zamanla kapanmış bir sürütme yolunun başlangıç-bitiş noktaları ve güzergâhı değerlendirilmiştir. Kullanılan test güzergâhı için üç farklı SAM planında kullanılan yatay kurp yarıçapları sırasıyla 200 m, 200 m, 77,64 m ve kiriş (chord) uzunlukları 25,50 m, 40,36 m, 37,15 m olarak belirlenmiştir (Şekil 5) (Tablo 1).

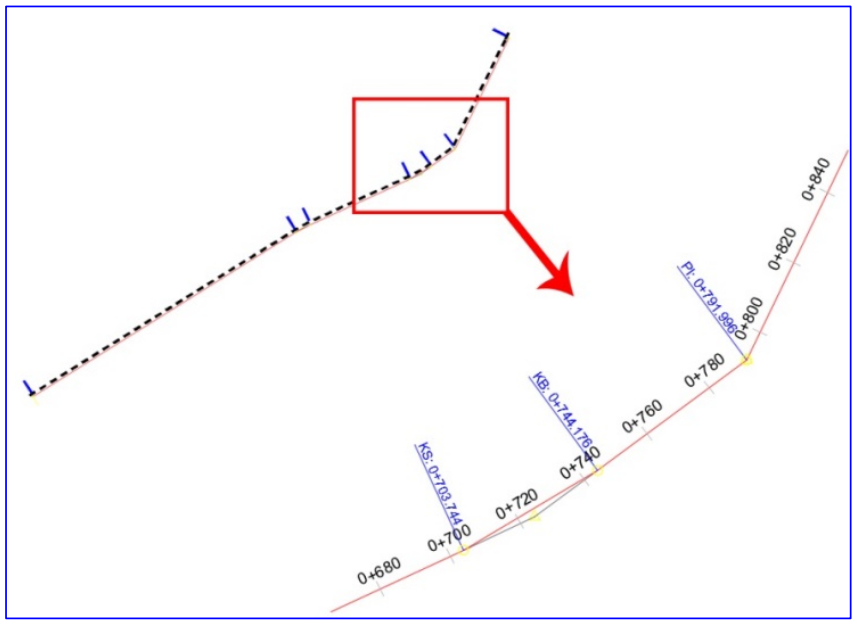

Şekil 5. Planlanan yola ait yatay geometri.

Tablo 1. Planlanan yola ait yatay yol geometri parametreleri.

\begin{tabular}{lllllllll}
\hline No & Tipi & $\begin{array}{l}\text { Uzunluk } \\
(\mathbf{m})\end{array}$ & $\begin{array}{l}\text { Yarıçap } \\
(\mathbf{m})\end{array}$ & $\begin{array}{l}\text { Yön } \\
\text { (grad) }\end{array}$ & $\begin{array}{l}\text { Başlangıç } \\
(\mathbf{m})\end{array}$ & $\begin{array}{l}\text { Bitiş } \\
(\mathbf{m})\end{array}$ & $\begin{array}{l}\text { Delta } \\
\text { Açısı } \\
\text { (grad) }\end{array}$ & $\begin{array}{l}\text { Kiriş } \\
\text { Uzunluğu } \\
\text { (m) }\end{array}$ \\
\hline $\mathbf{1}$ & Aliyman & 501,35 & & 64,22 & $0+000,00$ & $0+501,35$ & & \\
$\mathbf{2}$ & Kurp & 25,52 & 200,00 & & $0+501,35$ & $0+526,86$ & 8,12 & 25,50 \\
$\mathbf{3}$ & Aliyman & 176,88 & & 77,34 & $0+526,86$ & $0+703,74$ & & \\
$\mathbf{4}$ & Kurp & 40,43 & 200,00 & & $0+703,74$ & $0+744,18$ & 12,87 & 40,36 \\
$\mathbf{5}$ & Aliyman & 28,68 & & 59,47 & $0+744,18$ & $0+772,87$ & & \\
$\mathbf{6}$ & Kurp & 37,51 & 77,64 & & $0+772,87$ & $0+810,38$ & 30,75 & 37,15 \\
$\mathbf{7}$ & Aliyman & 181,58 & & 28,72 & $0+810,38$ & $0+991,96$ & & \\
\hline
\end{tabular}


Söz konusu planlanan yol güzergâhı 3 farklı SAM verisi dikkate alınarak boy kesiti oluşturulmuştur. Bu çalışmada, boy kesit için oluşturulan çizim tabanlı stil dosyasında düşey ölçek 1/200, yatay ölçek ise 1/100 olarak tanımlanmıştır (Şekil 6).

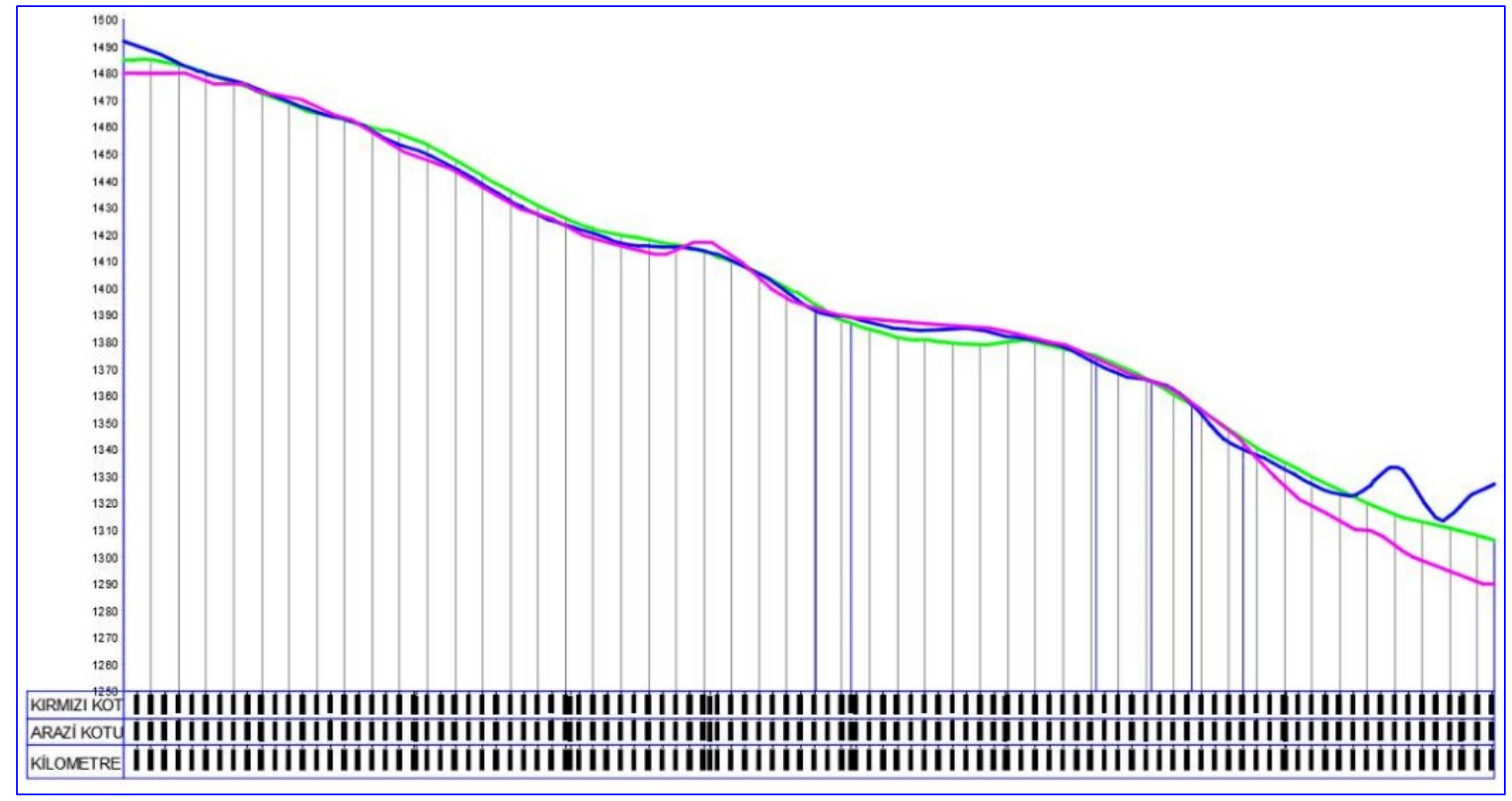

Şekil 6. Yol güzergâhına ait üç farklı sayısal arazi modeli için boy kesit profilleri.

Şekil 6'da görüldüğü üzere mavi, yeşil ve pembe olmak üzere planlanan yol güzergâhının geçtiği üç farklı arazi profili görülmektedir. Mavi renkteki arazi profili RTK-GPS tabanlı üretilen SAM, yeşil renkteki arazi profili SRTM verisi tabanlı üretilen SAM ve pembe renkteki arazi profili 1/25000 ölçekli topoğrafik harita tabanlı üretilen SAM'dır. Söz konusu üç farklı SAM verisi dikkate alınarak yola ait düşey profil çizilmiştir. Düşey profil oluşturulurken kazı dolgu dengelemesi dikkate alınarak manuel şekilde belirlenmiştir. Düşey profil Şekil 7'de kırmızı renk ile gösterilmiştir.

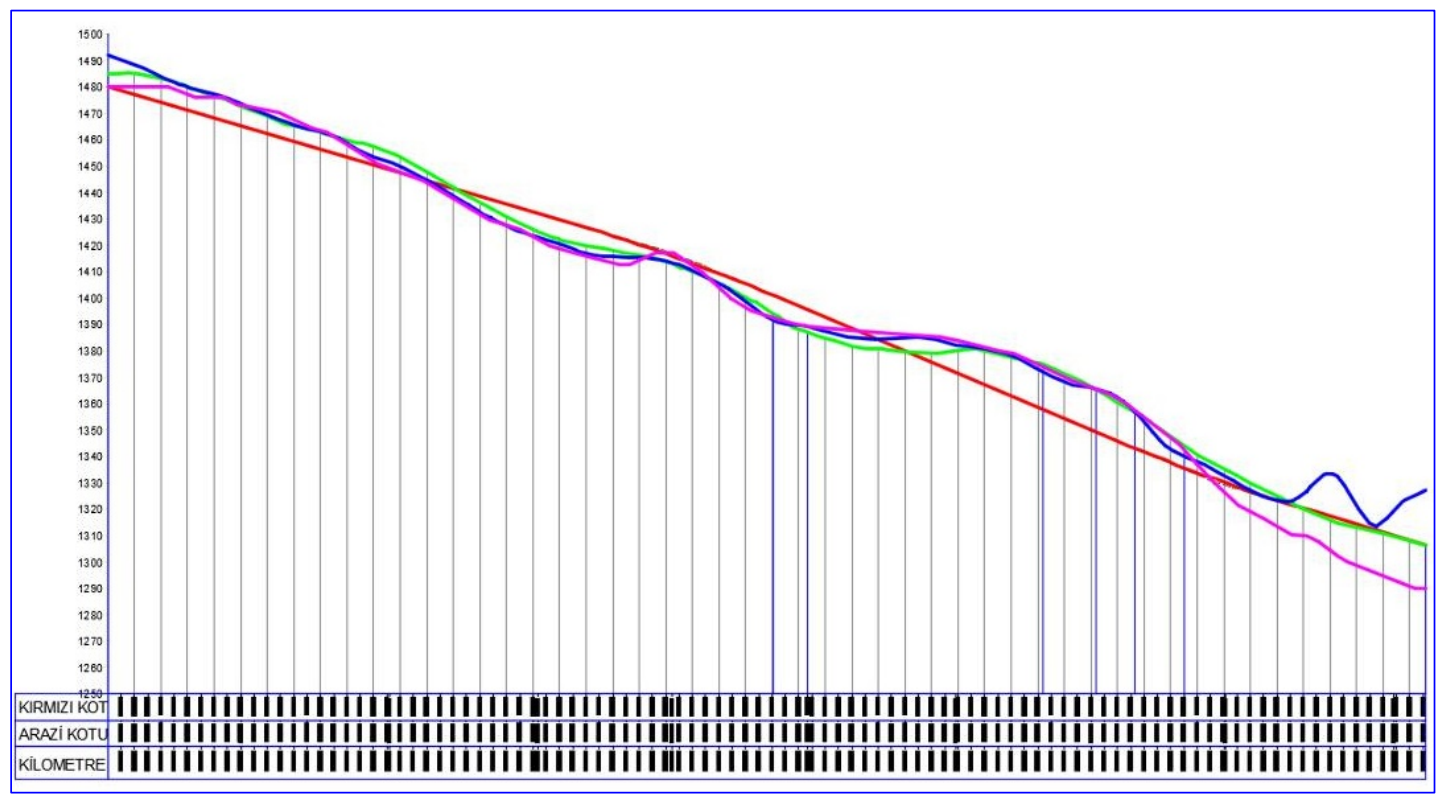

Şekil 7. Yol güzergâhına ait düşey profil ve arazi profilleri.

Buna göre düşey profil üzerinde \%14,85, \%21,26 ve \%25,23 olmak üzere üç farklı eğim ve profil kırılım noktalarında ise 2339 m ve 3379 m’lik yarıçaplı iki adet düşey kurp yol profiline ve yol tasarım kriterlerine göre yazılımda otomatik olarak hesaplanmıştır. (Tablo 2). Örnek güzergah için hesaplanan eğim ve kurp değerleri standart orman yolu kriterleri dışında çıkmıştır. 
Tablo 2. Planlanan yola ait boy kesit parametreleri

\begin{tabular}{|c|c|c|c|c|c|c|c|c|}
\hline \multirow{5}{*}{ 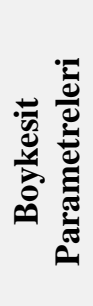 } & No & $\begin{array}{l}\text { Düşey some } \\
\text { noktasının } \\
\text { başlangıca } \\
\text { uzaklığı (m) }\end{array}$ & $\begin{array}{l}\text { Düşey some } \\
\text { noktasının } \\
\text { yüksekliği } \\
\text { (m) }\end{array}$ & $\begin{array}{l}\text { Eğim } \\
(\%)\end{array}$ & $\begin{array}{l}\text { Eğim } \\
\text { farkı } \\
(\%)\end{array}$ & $\begin{array}{l}\text { Düşey kurp } \\
\text { uzunluğu (m) }\end{array}$ & $\begin{array}{l}\text { K } \\
\text { değeri }\end{array}$ & $\begin{array}{l}\text { Düşey Kurp } \\
\text { yarıçapı (m) }\end{array}$ \\
\hline & 1 & $0+000,00$ & 1479,84 & & & & & \\
\hline & 2 & $0+426,14$ & 1416,55 & $\pm 14,85$ & 6,41 & 150,00 & 23,40 & 2339 \\
\hline & 3 & $0+833,25$ & 1330,00 & $\pm 21,26$ & 3,97 & 150,00 & 37,80 & 3379 \\
\hline & 4 & $0+991,96$ & 1289,96 & $\pm 25,23$ & & & & \\
\hline
\end{tabular}

Kübaj cetvelinin oluşturulması amacıyla standart B tipi orman yolu kesiti kullanılmıştır. Tip en kesit oluşturulurken, daha önce B tipi orman yolu için hazırlanan (kazıda 1:1, dolguda 2:3, hendekler 1 metre genişliğinde 1:3) tip kesit standartları kullanılmıştır (Şekil 8). Bu çalışmada, 292 sayılı tebliğde belirtilen şev oranları kullanmıştır. Şev oranlarının tanımlanması kullanılan program ara yüzünde farklılık gösterebilmektedir.

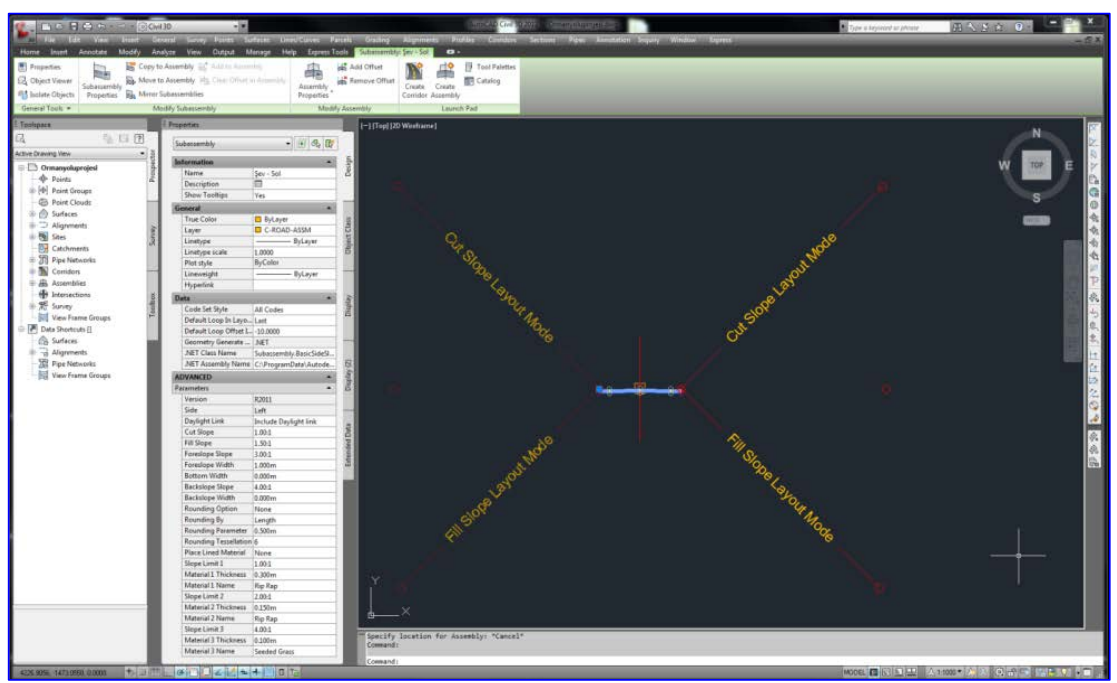

Şekil 8. Kullanılan tip kesit parametreleri.

Kazı ve dolgu hacmi hesaplarının hassasiyetini artırmak için kesit çizgileri güncellenerek 3B orman yolu koridoru oluşturulmuştur. Şekil 9'da görüldüğü üzere üç farklı veri setinde farklı şev yükseklikleri, şev eğimleri ve şev uzunlukları elde edilmiştir. Koridor modellemesi sonucu her bir farklı SAM verisi dikkate alınarak düşey profile göre en kesitler oluşturulmuştur (Şekil 10).

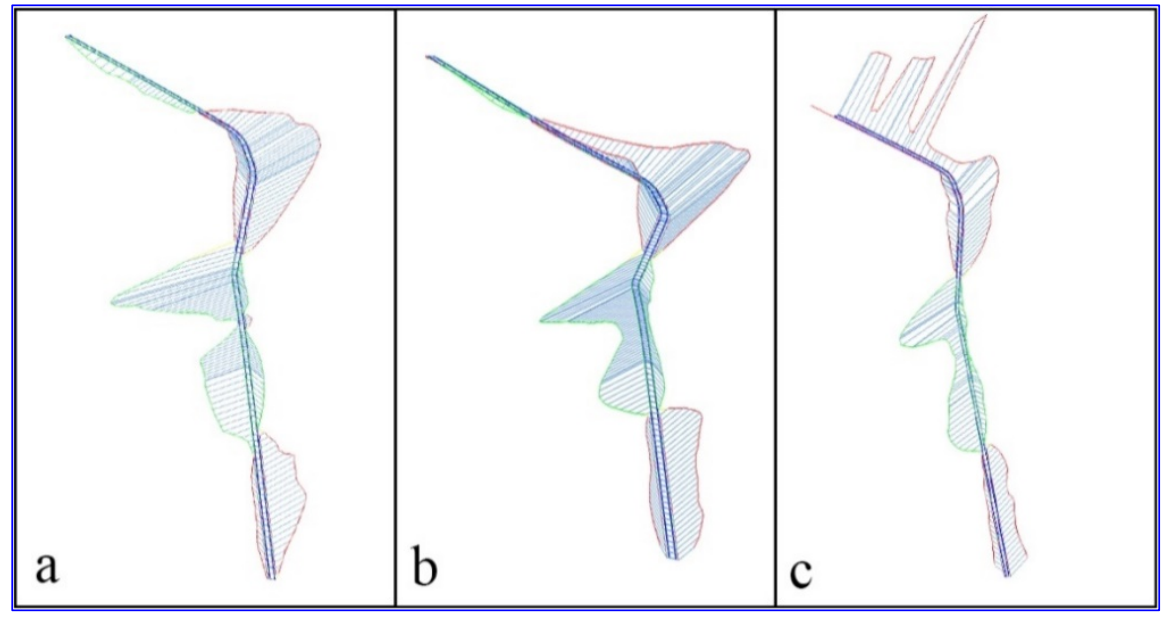

Şekil 9. 1/25000 ölçekli topoğrafik haritadan üretilen SAM a), SRTM den üretilen SAM b) ve RTK-GPS tabanlı üretilen SAM için c) 3B koridor modelleri. 


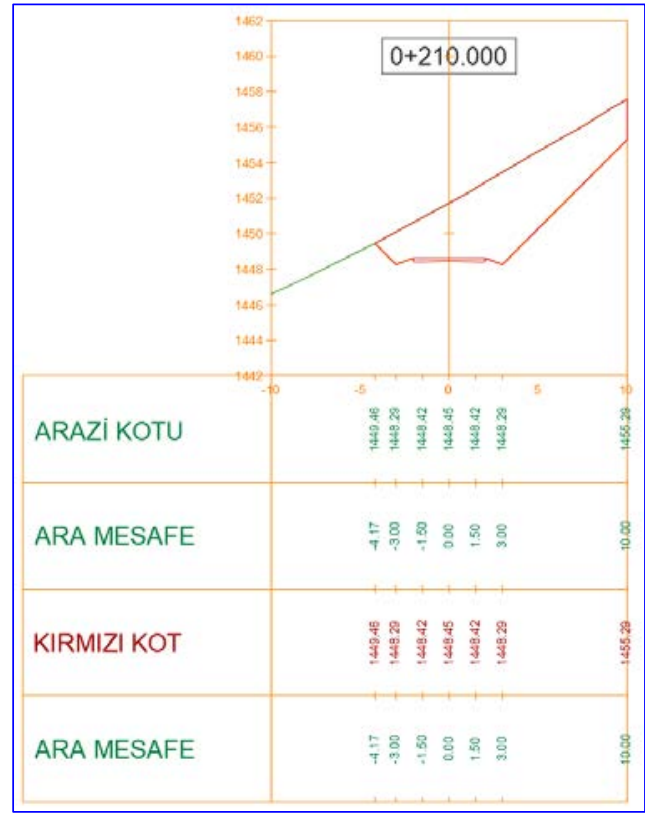

Şekil 10. Güzergâha ait bir en kesit örneği.

Ayrıca, her bir SAM verisi kendi içerisinde çalışma kapsamında kazı dolgu işlerini temsil etmek için kübaj cetvelleri elde edilmiştir (Tablo 3).

Tablo 3. Oluşturulan kübaj tablosu örnek şablonu.

\begin{tabular}{|c|c|c|c|c|c|}
\hline $\begin{array}{l}\text { Mesafe } \\
\text { (km) }\end{array}$ & $\begin{array}{l}\text { Ara } \\
\text { Mesafe } \\
\text { (m) }\end{array}$ & $\begin{array}{l}\text { Yarma } \\
\text { Alanı } \\
\left(\mathbf{m}^{2}\right)\end{array}$ & $\begin{array}{l}\text { Dolgu } \\
\text { Alanı } \\
\left(\mathbf{m}^{2}\right)\end{array}$ & $\begin{array}{l}\text { Yarma } \\
\text { Hacmi } \\
\left(\mathrm{m}^{2}\right)\end{array}$ & $\begin{array}{l}\text { Dolgu } \\
\text { Hacmi } \\
\left(\mathbf{m}^{3}\right)\end{array}$ \\
\hline $0+570,00$ & 10,00 & 0,00 & 2,72 & 0,00 & 3,87 \\
\hline $0+580,00$ & 10,00 & 18,65 & 4,82 & 93,25 & 1,60 \\
\hline $0+590,00$ & 10,00 & 49,42 & 0,00 & 34,04 & 0,24 \\
\hline $0+600,00$ & 10,00 & 85,64 & 0,00 & 67,53 & 0,00 \\
\hline $0+610,00$ & 10,00 & 12,13 & 0,00 & 10,35 & 0,00 \\
\hline $0+620,00$ & 10,00 & 14,95 & 0,00 & 13,54 & 0,00 \\
\hline $0+630,00$ & 10,00 & 16,62 & 0,00 & 15,78 & 0,00 \\
\hline $0+640,00$ & 10,00 & 18,26 & 0,00 & 17,44 & 0,00 \\
\hline $0+650,00$ & 10,00 & 21,16 & 0,00 & 19,64 & 0,00 \\
\hline $0+660,00$ & 10,00 & 23,84 & 0,00 & 22,43 & 0,00 \\
\hline $0+670,00$ & 10,00 & 26,19 & 0,00 & 25,01 & 0,00 \\
\hline $0+680,00$ & 10,00 & 27,29 & 0,00 & 26,74 & 0,00 \\
\hline $0+690,00$ & 10,00 & 26,67 & 0,00 & 26,98 & 0,00 \\
\hline $0+700,00$ & 10,00 & 25,42 & 0,00 & 26,05 & 0,00 \\
\hline $0+703,74$ & 3,74 & 25,03 & 0,00 & 9,11 & 0,00 \\
\hline $0+705,00$ & 1,16 & 24,93 & 0,00 & 31,38 & 0,00 \\
\hline $0+710,00$ & 5,00 & 2,45 & 0,00 & 12,46 & 0,00 \\
\hline $0+715,00$ & 5,00 & 2,43 & 0,00 & 12,31 & 0,00 \\
\hline $0+720,00$ & 5,00 & 2,43 & 0,00 & 1,23 & 0,00 \\
\hline $0+723,96$ & 3,96 & 2,46 & 0,00 & 0,98 & 0,00 \\
\hline
\end{tabular}


Çalışma kapsamında oluşturulan farklı SAM üretim teknikleri kullanılarak oluşturulan toplam kazı dolgu hesapları dikkate alındığında; dolgu hacmi en yüksek SRTM verisinde, en düşük ise 1/25000 ölçekli topoğrafik harita kaynaklı üretilen SAM verisinden elde edilmiştir (Tablo 3). Kümülatif kazı hacimleri dikkate alındığında ise en yüksek değerler ile RTK-GPS kaynaklı SAM verisinden elde edilirken, en düşük değer ise SRTM kaynaklı SAM verisinden elde edilmiştir (Tablo 4).

Tablo 4. Farklı SAM kaynaklı kazı-dolgu hesapları.

\begin{tabular}{llllll}
\hline $\begin{array}{l}\text { SAM Üretim } \\
\text { Kaynağı }\end{array}$ & $\begin{array}{l}\text { Toplam } \\
\text { dolgu hacmi } \\
\text { (\%) }\end{array}$ & $\begin{array}{l}\text { Toplam } \\
\text { kazı hacmi } \\
(\%)\end{array}$ & $\begin{array}{l}\text { Toplam yol } \\
\text { uzunluğu } \\
\text { (m) }\end{array}$ & $\begin{array}{l}\text { Kümülatif dolgu } \\
\text { hacmi enkesit } \\
\text { başına }\end{array}$ & $\begin{array}{l}\text { Kümülatif kazı } \\
\text { hacmi enkesit } \\
\text { başına }\end{array}$ \\
\hline $\begin{array}{l}\text { 1/25000 ölçekli } \\
\text { topoğrafik }\end{array}$ & 31,92 & 68,08 & 991,57 & 23,46 & 50,04 \\
$\begin{array}{l}\text { harita } \\
\text { SRTM }\end{array}$ & & & & \\
RTK-GPS & 47,12 & 52,88 & 991,57 & 34,37 & 38,58 \\
\hline
\end{tabular}

En kesit başına düşen kazı-dolgu hacimleri dikkate alındığında ise en yüksek dolgu hacmi 34,37 $\mathrm{m}^{3}$ ile SRTM verisi kaynaklı oluşturulan SAM verisinden elde edilirken, en düşük dolgu hacmi ise 27,23 $\mathrm{m}^{3}$ ile RTK-GPS kaynaklı SAM verisinden elde edilmiştir. En kesit başına düşen kazı-dolgu hacimleri dikkate alındığında ise en yüksek kazı hacmine 89,95 m³ ile RTK-GPS verisi kaynaklı SAM verisinden elde edilirken, en düşük kazı hacmi ise 38,58 $\mathrm{m}^{3}$ ile SRTM verisi kaynaklı oluşturulan SAM verisinden elde edilmiştir.

\subsection{En uygun maliyetli güzergâhın belirlenmesi}

Araştırma alanı içerisinde 84 no’lu bölmede bulunan Göknar türüne sahip olan ve "Gen Koruma" statüsünde bulunan alanda inşa edilmesi tasarlanan orman yolu güzergâhı için en uygun maliyetli güzergâhı hesaplanmıştır. Bu hesaplamada SAM verileri geçirimsiz katman yüzeyi olarak kullanılmış olup raster veri üzerinde başlangıç ve bitiş noktalarına ulaşılacak en uygun eğime sahip güzergâh ortaya konmuştur. Eğimi dikkate alarak en düşük eğime sahip yol güzergâhı için başlangıç ve bitiş noktaları belirtilmiştir. Şekil 11'de her üç SAM ile belirlenen güzergâhlar verilmiştir. Ayrıca, SAM'lardan elde edilen güzergâhlara ait sayısal veriler Tablo 5'te belirtilmiştir.

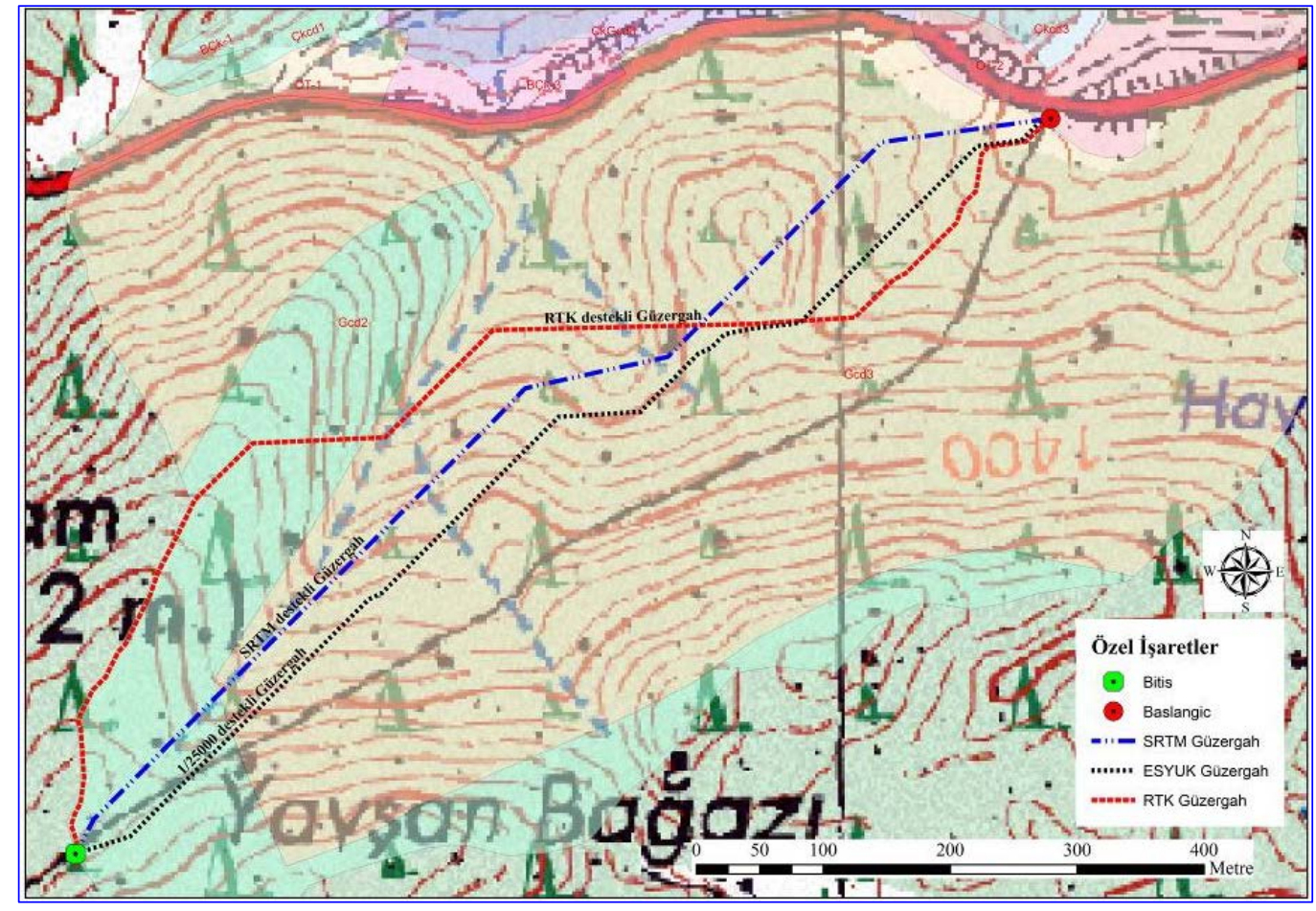

Şekil 11. Farklı SAM'ler kullanılarak CBS ortamında en uygun maliyetli güzergâh analizi ile belirlenen alternatif yollar 
Tablo 5. En uygun maliyetli yol güzergâhlarına ait veriler

\begin{tabular}{llll}
\hline SAM Kaynağı & $\begin{array}{l}\text { Yol Uzunluğu } \\
(\mathbf{m})\end{array}$ & Yatay Kurp Sayısı & $\begin{array}{l}\text { Ortalama Yol } \\
\text { Boyuna Eğimi } \\
\text { (\%) }\end{array}$ \\
\hline SRTM & 1001,83 & 7 & 18,9 \\
RTK & 1116,05 & 8 & 17,0 \\
1/25000 ölçekli topoğrafik harita & 998,19 & 4 & 19,0 \\
\hline
\end{tabular}

\section{Sonuç ve Tartışma}

1/25000 ölçekli topoğrafik harita tabanlı elde edilen toplam kazı miktarı 50,04 $\mathrm{m}^{3}$ ve dolgu miktarı 23,46 $\mathrm{m}^{3}$ olarak hesaplamıştır. SRTM'den elde edilen toplam kazı miktarı 38,58 $\mathrm{m}^{3}$ ve dolgu miktarı 34,37 $\mathrm{m}^{3}$ olarak hesaplanmıştır. RTK tekniğine göre elde edilen toplam kazı miktarı 89,95 $\mathrm{m}^{3}$ ve dolgu miktarı 27,23 $\mathrm{m}^{3}$ olarak hesaplanmıştır (Tablo 4). Toplam uzunluğu 991,57 m olan yol güzergâhında en fazla kazı miktarı sırasıyla RTK> SRTM > 1/25000 ölçekli topoğrafik harita üzerinden belirlenirken, toplam dolgu hacim miktarları ise sırasıyla SRTM $>1 / 25000$ ölçekli topoğrafik harita > RTK SAM olarak ortaya çıkmıştır (Tablo 4). Bu çalışmada belli iki nokta arasında bulunan sabit bir test güzergâhı için kazı dolgu farkları SAM verileri için değerlendirilmiştir. Orman yolu maksimum ve minimum eğimler 292 sayılı tebliğde belirtilen standartların dışındadır. Bahsedilen kazı-dolgu dengesi, yol yapımı sırasında doğaya en az tahribatı verecek güzergâhın belirlenmesi koşulunu irdelememize yardımcı olmaktadır. Arazi çalışmalarındaki detayların önemi ve arazide yol güzergâhının en ince ayrıntısına kadar incelenmesi çevreye daha duyarlı orman yolu oluşturulmasına yardımcı olacaktır.

Çevreye daha duyarlı doğala daha yakın bir planlama için SAM verisi oldukça önemlidir (Lugo ve Gucinski, 2000; Tunay, 2006; Gümüş vd., 2008; Acar, 2016; Boston, 2016). Dolayısıyla eski bir güzergâhın test edildiği bu çalışmada, kazı-dolgu hacmi dengesizliğine bakıldığında alternatif güzergâhlarında belirlenmesi gerekmektedir. Bu araştırma kapsamında en uygun maliyetli güzergâh analizi sonuçlarına göre daha az ortalama arazi eğimine, en uzun ve en fazla kurp miktarına sahip yolu önermektedir (Şekil 11). Çalışmada eğime göre hesaplanan en uygun maliyetli güzergâhın en uzun yol güzergâhı ve en düşük ortalama yol eğimine sahip güzergâh RTK-GPS yöntemi ile tahmin edilmiştir (Tablo 5). Alternatif olarak belirlenen güzergâhlarda yol projelendirilmemiş olup yalnızca kazı-dolgu analizleri gerçekleştirilmemiştir. Nitekim proje aşamasında RTK-GPS tabanlı SAM'ın kullanılması ile daha hassas güzergâh tahmini gerçekleştirildiği görülmektedir (Şekil 11).

Karar destek sistemlerinin kullanıldığı orman yolu planlama çalışmalarında başarının arttırılmasında uzman görüşlerinin de alınarak değerlendirilmesi etkili olmaktadır (Acar vd., 2017). Bu nedenle ileriki çalışmalarda orman yolu güzergâhının belirlenmesindeki hassasiyetin ekonomik maliyet bakımından değerlendirilmesi de gerekmektedir. Bunun için topoğrafik verilerin yanı sıra meşcere parametreleri, dereye uzaklık, zemin bilgisi gibi parametrelerin analizlerde kullanılması gerekmektedir. Tüm bu planlama ve maliyet çalışmaları yanında orman yolu yapımında uygun makinenin seçilmesi ve operatör eğitimleri de etkendir. Yine, yol görüş mesafesi ile kazı-dolgu ilişkilerinin ortaya konulmasıyla daha ekolojik, ergonomik, estetik ve ekonomik analizlere katkı sağlayacak çalışmalar gerçekleştirilebilir (Arıcak ve Acar, 2008; Acar, 2016; Tunay vd., 2001; Şentürk vd., 2018).

RTK-GPS tekniğinin orman yollarının planlanması veya inşaat işlerini içeren mühendislik projesi çalışmalarında veri kullanılabilirliği incelenmiştir. SRTM verisi ile elde edilen SAM çözünürlüğü $30 \mathrm{~m}$, topoğrafik harita tabanlı SAM için $10 \mathrm{~m}$ ve RTK-GPS tabanlı üretilen SAM çözünürlüğü ise 5 m olarak elde edilmiştir. RTK-GPS tabanlı SAM, arazi çalışmalarını içeren mühendislik çalışmalarında olduğu gibi orman yolu projelendirilmesinde de arazi topoğrafyasının gerçeğe daha SAM ile ortaya konulabilmektedir.

Kazı-dolgu işlerinin daha doğru hesaplanması maliyeti doğrudan etkilediğinden çalışma sonucu göstermiştir ki RTK-GPS den elde edilen SAM verilerinin diğer SAM verilerine göre daha gerçekçi sonuçlar sağladığı görülmektedir. SRTM ve memleket paftasından türetilen SAM'ler zamansal olarak esneklik sağlamazken, RTK-GPS verileri ise alım zamanına bağlı olarak güncel veri temini ile aktüel arazi topoğrafyasına ait veri sağlanabilmektedir.

Ayrıca bu çalışma kapsamında sonuçlar değerlendirildiğinde; 
- RTK-GPS ölçümlerinde elde edilen doğrulukları yatayda ve düşeyde diğer yöntemlere göre daha başarılıdır.

- RTK-GPS tekniği, hassas veri elde etmeye olanak sağlamaktadır. Ancak, eğimli ve kayalık arazilerde, yüksek kapalılığa sahip ağaçlık ve çalılık alanlarda uygulanması zordur. Ölçüm zorluğu nedeniyle elde edilen veri hassasiyeti ve doğruluğu azalmaktadır.

- Mutlak doğruluğun istendiği mühendislik ölçümlerini kapsayan projelerde süreklilik ve hassasiyet isteyen ormancılık çalışmalarda uygulanmalıdır.

- Orman içi ve kenarı alanlarda yapılan uygulamada hata sınır değerleri farklılık göstermektedir.

- Sabit nokta tesisi ve hesabı problemi yapmaya gerek kalmadan doğrudan konum verisi alınan RTK-GPS yöntemi ile konum bilgisi kolaylıkla elde edilmektedir.

- Alternatif yol güzergâhlarının tespit edilmesi amacıyla en uygun maliyetli güzergâh analizleri kullanılabilmektedir.

\section{Teşekkür}

Bu çalışma, Kahramanmaraş Sütçü İmam Üniversitesi Bilimsel Araştırma Projeleri Koordinasyon Birimi (No:2016/372M) tarafından desteklenen çalışma verilerini içermektedir. Arazi çalışmalarına katılan Orman Mühendisi Harun Önen'e teşekkür ederiz. Yazarlar, bu makalenin iyileştirilmesinde sunmuş oldukları görüş ve katkılarından dolayı derginin editörüne ve hakemlerine teşekkür etmektedirler.

\section{Kaynaklar}

1. Abdi, E., Majnounian, B., Darvishsefat, A., Mashayekhi, Z., Sessions, J. (2009). A GIS-MCE Based Model for Forest Road Planning. Journal of Forest Science, 55(4), 171-176.

2. Abdi, E., Sisakht, S.R., Goushbor, L., Soufi, H. (2012). Accuracy Assessment of GPS and Surveying Technique in Forest Road Mapping. Annals of Forest Research, 55(2), 309-317.

3. Acar, H.H., (2016). Environmental Sensitive Road Planning and Transportation Techniques in Forest Engineering. Journal of the Faculty of Forestry Istanbul University, 66(2), 710-726.

4. Acar, H.H., Dursun, E., Gulci, S., Gumus, S., (2017). Assessment of Road Network Planning By Using Gis-based Multi-Criteria Evaluation for Conversion of Coppice Forest to High Forest. Fresenius Environmental Bulletin, 26(3): 2380-2388.

5. Adriaensen, F., Chardon, J.P., De Blust, G., Swinnen, E., Villalba, S., Gulinck, H., Matthysen, E. (2003). The Application of "Least-Cost" Modelling as a Functional Landscape Model. Landscape and Urban Planning, 64(4), 233-247.

6. Akay, A.E. (2004). A New Method of Designing Forest Roads. Turkish Journal of Agriculture and Forestry, 28(4), 273-279.

7. Akay, A.E., Sessions, J. (2005). Applying the Decision Support System, TRACER, to Forest Road Design. Western Journal of Applied Forestry, 20(3), 184-191.

8. Akay, A.E., Oğuz, H., Karas, I.R., Aruga, K. (2009). Using LiDAR Technology in Forestry Activities. Environmental Monitoring and Assessment, 151(1), 117-125.

9. Akay, A.E., Sivrikaya, F., Gülci, S. (2014). Analyzing Riparian Forest Cover Changes along the Firniz River in the Mediterranean City of Kahramanmaras in Turkey. Environmental Monitoring and assessment, 186, 2741-2747.

10. Akay, A.O., Demir, M., Akgul, M. (2018). Assessment of Risk Factors in Forest Road Design and Construction Activities with Fuzzy Analytic Hierarchy Process Approach in Turkey. Environmental Monitoring and assessment, 190,561.

11. Akgul, M., Demir, M., Ozturk, T., Topatan, H., Budak, Y.E. (2016a). Investigation of Recreational Vehicles Maneuverability on Forest Roads by Computer-Aided Driving Analysis. The Baltic Journal of Road and Bridge Engineering, 11(2), 111-119.

12. Akgül, M., Yurtseven, H., Demir, M., Akay, A.E., Gülci, S., Öztürk, T. (2016b). İnsansız Hava Araçları ile Yüksek Hassasiyette Sayısal Yükseklik Modeli Üretimi ve Ormancılıkta Kullanım Olanaklar1. Journal of the Faculty of Forestry Istanbul University, 66(1), 104-118.

13. Akgul, M., Yurtseven, H., Gülci, S., Akay, A.E. (2018). Evaluation of UAV- and GNSS-Based DEMs for Earthwork Volume. Arabian Journal for Science and Engineering, 43(4), 1893-1909.

14. Akturk, E., Altunel, A.O. (2019). Accuracy Assessment of a Low-Cost UAV Derived Digital Elevation Model (DEM) in a Highly Broken and Vegetated Terrain. Measurement, 136:382-386. 
15. Aricak, B. (2015). Using Remote Sensing Data to Predict Road Fill Areas and Areas Affected by Fill Erosion with Planned Forest Road Construction: A Case Study in Kastamonu Regional Forest Directorate (Turkey). Environmental Monitoring and Assessment, 187, 417.

16. Arıcak, B., Acar, H. H. (2008). The Modeling of Filling and Construction Impact Areas in Building Forest Roads by Using Quickbird Satellite Image. Kastamonu University Journal of Forestry Faculty, 8(2),144-156.

17. Aslan, Ş.T.A. (2005). Coğrafi Bilgi Sistemi Olanakları ile Bazı Havza Özelliklerinin Belirlenmesi. KSÜ Fen ve Mühendislik Dergisi, 8(2),128-134.

18. Boston, K. (2016). The Potential Effects of Forest Roads on the Environment and Mitigating their Impacts. Current Forestry Reports, 2,215-222.

19. Chung, W., Sessions, J. (2001). Designing a Forest Road Network using Heuristic Optimization Techniques. Appalachian Hardwood: Managing Change, Corvallis, Oregon.

20. Demir, M. (2007). Impacts, Management and Functional Planning Criterion of Forest Road Network System in Turkey. Transportation Research Part A Policy and Practice, 41(1), 56-68.

21. Eker, M., Coban, H.O. (2010). Impact of Road Network on the Structure of a Multifunctional Forest Landscape Unit in Southern Turkey. Journal of Environmental Biology, 31(1-2), 157-68.

22. Erdaş, O., (1997). Orman Yolları, Karadeniz Teknik Üniversitesi Orman Fakültesi, Yayın No:187, 298 S., Trabzon.

23. Grigolato, S., Mologni, O., Cavalli, R. (2017). GIS Applications in Forest Operations and Road Network Planning: An Overview over the Last Two Decades. Croatian Journal of Forest Engineering, 38(2), 175-186.

24. Gülci, N., Akay, A.E., Erdaş, O., Gülci, S. (2015a). Üretim İşlerinin Planlanmasında RTK-GPS Tabanlı Sayısal Yükseklik Modelinin Kullanılması. İstanbul Üniversitesi Orman Fakültesi Dergisi, 65(2), 59-68.

25. Gülci, S., Akay, A.E. (2015). Assessment of Ecological Passages along Road Networks within the Mediterranean Forest using GIS-Based Multi Criteria Evaluation Approach. Environmental Monitoring and Assessment 187, 779.

26. Gülci, S., Akay, A.E., Oguz, H., Gülci, N. (2017a). Assessment of the Road Impacts on Coniferous Species within the Road-Effect Zone Using NDVI Analysis Approach. Fresenius Environmental Bulletin 26(2a),1654-1662.

27. Gülci, S., Yüksel, K., Gülci, N. (2017b). Elevation Error Comparison of Commonly Used Digital Elevation Models (DEM) for Natural Resource Management with Ground Control Points. Middle East Journal of Science, 3(1), 9-19.

28. Gümüş, S., Acar H.H., Tunay, M., Ateşoğlu, A. (2003). Calculation of Cut and Fill Volumes By GIS in Forest Roads Projecting. XII World Forestry Congress, A, 152-153 p, 21 - 28 Sept 2003, Quebec, Canada.

29. Gümüş, S., Acar, H.H., Toksoy, D. (2008). Functional Forest Road Network Planning by Consideration of Environmental Impact Assessment for Wood Harvesting. Environmental Monitoring and Assessment, 142, 109-116.

30. Hayati, E., Majnounian, B., Abdi, E., Sessions J., Makhdoum, M. (2013). An Expert-Based Approach to Forest Road Network Planning by Combining Delphi and Spatial Multi-Criteria Evaluation. Environmental Monitoring and Assessment, 185, 1767-1776.

31. Heinimann, H.R. (2017). Forest Road Network and Transportation Engineering - State and Perspectives. Croatian Journal of Forest Engineering, 38(2), 155-173.

32. Lepoglavec, K., Potočnik, I., Pentek, T., Poje, A., Mihelič, M. (2012). »RoadEng« Software Package for Designing Forest Roads. New For Mech, 32, 39-51.

33. Lugo, A.E., Gucinski, H. (2000). Function, Effects, and Management of Forest Roads. Forest Ecology and Management, 133(3), 249-262.

34. Najafi, A., Richards, E.W. (2013). Designing a Forest Road Network Using Mixed Integer Programming. Croatian Journal of Forest Engineering, 34(1), 17-30.

35. Nelson, A., Reuter, H.I., Gessler, P. (2009). Dem Production methods and sources. Developments in Soil Science, 33, 65-85.

36. OGM. (2008). Orman Yolları Planlanması ve İnşaat İşlerinin Yürütülmesi, 292 Sayılı Tebliğ. Ankara.

37. OGM. (2012). Başkonuş Orman İletme Şefliği Fonksiyonel Orman Amenajman Planı (IV. Yenileme), Orman Genel Müdürlüğü. 573 s. Ankara.

38. Öztürk, T. (2009). Orman Yolu Planlarının Oluşturulmasında Netpro Yol Modülünün Kullanılması. Eskişehir Osmangazi Üniversitesi Mühendislik Mimarlık Fakültesi Dergisi, 12(3), 11-21.

39. Şentürk, N., Akgül, M., Öztürk, T., Akay, A.O. (2018). Orman Yollarında Kazı-Dolgu Miktarlarının Hesaplanmasında Topoğrafik Harita Tabanlı Geleneksel Yöntem ile Bilgisayar Destekli Yöntemin Karşılaştırılması. Bartın Orman Fakültesi Dergisi, 20, 618-626. 
40. Tampekis, S., Sakellariou, S., Samara, F., Sfougaris, A., Jaeger, D., Christopoulou, O. (2015). Mapping the Optimal Forest Road Network based on the Multicriteria Evaluation Technique: The Case Study of Mediterranean Island of Thassos in Greece. Environmental Monitoring and Assessment, 87, 687.

41. Tunay, M. (2006). The Assessment of Environmentally Sensitive Forest Road Construction in Calabrian Pine Forest Areas of Turkey. Journal of Environmental Biology, 27(3):529-35.

42. Tunay, M., Acar H.H., Ateşoğlu, A. (2001). Orman Yollari Projelendirmede Kazi-Dolduru Hacimlerinin Bilgisayar Ortaminda Hesabi. ZKÜ Bartın Orman Fakültesi Dergisi, 3(3), 45-58.

43. Türk, Y. (2019). Forest Road Design with Cad Software: A Case Study in the Western Black Sea Region of Turkey. Fresenius Environmental Bulletin, 28(3), 1743-1751.

44. Wilson, J.P. (2012). Digital Terrain Modeling. Geomorphology, 137,107-121.

45. Yu, C., Lee, J., Munro-Stasiuk, M.J. (2003). Extensions to Least-Cost Path Algorithms for Roadway Planning. International Journal of Geographical Information Science, 17(4), 361-376.

46. Yurtseven, H. (2019). Comparison of GNSS-, TLS- and Different Altitude UAV-Generated Datasets on the Basis of Spatial Differences. International Journal of Geo-Information, 8(4), 175.

47. Zhang, H., Zheng, J., Dorr, G., Zhou, H., Ge, Y. (2014). Testing of GPS Accuracy for Precision Forestry Applications. Arabian Journal for Science and Engineering, 39, 237-245. 